\title{
EXPLORATION LOCAL CULTURE A CONSERVATION CULTURE THROUGH PROJECT-BASED LEARNING TO INCREASE WRITING ABILITY JAPANESE THE SECONDARY LEVEL
}

\author{
Lispridona Diner ${ }^{1}$, Dwi Puji Asrini ${ }^{2}$ \\ \{lisjoost@yahoo.com ${ }^{1}$,dwipujuasrini82@gmail.com $\left.{ }^{2}\right\}$ \\ ${ }^{1,2}$ Universitas Negeri Semarang Kampus Sekaran Gunungpati Semarang, Indonesia
}

\begin{abstract}
Japanese language writing skills start from semester 1, namely writing hiragana, katakana, and kanji. The difficulties of students in writing are lack of knowledge gained, lack of mastery of sentence patterns and vocabulary. The results of technological advancements such as the easiness access to the internet make most students get information about foreign cultures. Based on observations, students' knowledge about local culture is still lacking, so it becomes an obstacle in writing. The other problem is the ability to compose sentences into paragraphs, discourse, or even become a systematic essay. Lack of knowledge in the local culture in Central Java also becomes another problem. This phenomenon is experienced by $4^{\text {th }}$-semester students in sakubun chukyu zenhan courses. Therefore, researchers need to explore the ability to write in the form of project learning as an effort to conserve culture through a project-based learning model.In the learning process of sakubun chukyu zenhan, the teacher gives a theme of local culture in writing essays in Japanese. It is done to realize cultural conservation in which Japanese (Japanese tourists) will easily find out about the local culture in Central Java.
\end{abstract}

Keywords: Culture, Project-Based Learning

\section{INTRODUCTION}

Language is a communication tool to convey messages to others both orally and in writing. The message delivered can vary, such as messages in the form of "commands", "suggest", "impression", and so forth. Oral language can be conveyed through spoken and gesture devices, while written language is expressed through writing. Language can be learned through formal education or informal education. Language learning through formal education today is a basic need for community education. Besides learning Javanese, Indonesian, and English, there are also other foreign languages such as Japanese, French, Arabic, and Mandarin. The community believes that through learning a foreign language, they have higher employment opportunities or business opportunities. 
Higher education, as the highest education provider, responds quickly to the needs of the community by opening a language and literature study program. Semarang State University (Unnes) is one of the tertiary institutions that has Faculty of Language and Art and in which there is language and literature education. Especially at the Department of Foreign Languages and Literature Study Program (Study Program), Japanese Language Education is one of the study programs that are of interest to prospective students.

The learning process in the Japanese Language Education Study Program is based on student centers, for example, in subjects sakubun (writing skills). The writing skills of Japanese students start from semester 1, namely writing hiragana, katakana, and kanji. Nevertheless, that semester was not in the form of a series of paragraphs or essays. Writing skills in a series of paragraphs and essays begin in semester 2, namely the sakubun shokyu (basic writing) course.

Nevertheless, the difficulty of students in writing is the lack of acquired knowledge (not like reading), lack of mastery of sentence patterns, and vocabulary. Besides, as a result of technological advances such as easy access to the internet so that most students indirectly obtain information about foreign cultures. Based on observations, students' knowledge of local culture still lacks, so that it becomes an obstacle in writing. Based on interviews with several students, some students do not know the name of the activities carried out in their city every year.

A side of the ability to string a sentence to be a paragraph to discourse becomes an essay that systematic. Lack of knowledge, especially in the local culture, is in central java, which is happening in Japanese language learners in Unnes. According to observed and interviewed, they come from the city or district in central java. Still, they lack the knowledge of their native regions, culture, like a celebration being made by the local community, the habit of the community, dance and music as well as geographical location. According to observation and interview, it was because of technological development and made the trait of being increased. It was not in line with the visions of Unnes in which it is declared, conservation and cultural conservation, the environment and conservation values, and character.

The above phenomenon is experienced by the 4th semester students in the chukyu zenhan sakubun course (Writing early intermediate level). Hence, researchers bother doing digging since writing learning in the form of project learning as an effort to kind of classroom culture through conservation project-based learning. It is expected that after following a course called sakubun knowledge, students with the culture localized in central java suffering an accelerated greenhouse an increase in, since writing and the result has been an increase in learning from the lecture sakubun can reach the maximum scores.

On the learning process sakubun chukyu zenhan, teachers give the local culture in writing a wreath with Japanese. It is done to create a conservation culture where the Japanese (Japanese tourists) can easily know the local culture that is in Central Java. Hence, research must be called "Exploration Local Culture a Conservation Culture Through Project-Based Learning to Increase Writing Ability Japanese the Secondary Level". The theory is the definition that is given to research project-based learning, conservation, culture, and the ability of creative thinking.[5]

Project-Based Learning or usual abbreviated PJBL. Project-based learning is a model of learning that uses as a medium. Learners explore, evaluate, interpret, synthesize, and information to produce various forms of learning outcomes. [1]

A learning-based project is a learning model, which is using as a first step in collecting and integrate new knowledge based on his experiences in exertion significantly. Learning-based project designed for use on the complex necessary school tuition in doing investigation and 
understand. Through PJBL, the inquiry began with a (guiding a question) and guiding students in a collaborative project that integrates various subjects in the curriculum. When the question is answered, students can directly see a variety of main elements as well as various principles in a discipline that is being studied. [2]

Unnes Rector's Regulation No. 27 of 2012 concerning campus governance at Semarang State University article 3 paragraph 1 and 2, written about campus governance is realized through the seven main pillars of the Conservation University, namely: 1. Conservation of biodiversity 2 . Green architecture and internal transportation system 3. Waste management 4. Non-paper policy 5. Clean energy 6. Conservation of ethics, art, and culture 7. Conservation regeneration on the sixth pillar, namely conservation of ethics, art, and culture. The pillars of conservation of ethics, art, and culture aim to preserve and develop local ethics, arts, and culture to strengthen national identity. The pillar program of the conservation of ethics, arts, and local culture through the maintenance, documentation, education, dissemination, and promoting its elements. The work unit is obliged to explore local cultural values and implement, develop, manage, monitor, and evaluate the pillars of ethical, artistic, and cultural conservation programs. The work unit is obliged to organize activities and provide facilities to support the preservation and development of regional ethics, arts, and culture. Unnes residents are required to develop and preserve local culture in activities on campus and its surroundings. Provisions for implementing the ethics, arts, and culture conservation pillar program are regulated in the quality procedures for the ethics, arts, and culture conservation pillar program. [3]

Munandar said the characteristics of creativity ability related to cognition could be seen from fluent thinking skills, flexible thinking skills, original thinking skills, and assessment skills. Good thinking skills have the following characteristics: (1) sparking lots of ideas in solving problems; (2) giving many ways or suggestions to do various things; (3) work faster and do more than others. The ability to think flexibly has the following characteristics: (1) generating ideas for problem-solving or answers to a variety of questions; (2) can see a problem from different points of view; (3) presents a concept in a different way. [4]

Japanese language learning to improve writing skills in Japanese study programs, namely in sakubun, unconditional tiered subjects. Obtained by students in semester 2, sakubun shokyu, sakubun shochukyu, sakubun chukyu zenhan, sakubun chukyu kohan and sakubun enshu (semester 7)

\section{METHOD}

The method used in this research is an experimental method that is a method that aims to test the effect of a variable or test how the causal relationship between one variable with another variable. [5] The experimental method used in this study is truly experimental. The population and sample in this study were all Japanese Language Education Study Program students taking sakubun lectures or writing skills. The data collection technique used is a test.

\section{RESULT AND DISCUSSION}

This writing process uses project-based learning. Students are divided into four groups. 
Table 1. Division of Groups by City

\begin{tabular}{|c|l|c|}
\hline Group & \multicolumn{1}{|c|}{ City } & Person \\
\hline 1 & Semarang & 8 \\
\hline 2 & Solo & 8 \\
\hline 3 & Pekalongan & 8 \\
\hline 4 & Banyumas & 8 \\
\hline
\end{tabular}

Four cities were chosen based on the consideration of several students from the city. After being divided into four groups consisting of 8 students, each group is divided into four themes, namely "tourist attractions", "traditional celebrations", "traditional cuisine" and "traditional souvenirs".

Writing is done in the following stages: 1.Preparation (group division, theme division) 2. Search for information 3. Write Initial paragraph 4. Correction (Student-Lecturer) 5. Write a paragraph of Content 6. Correction (Student-Lecturer) 7. Write the final paragraph 8. Correction (Student-Lecturer)

From 32 respondents, it can be seen the average value of students' ability to write on the aspect of the theme is $80 \%$ included in either category.

Table 2. The ability to write students on aspects of the theme

\begin{tabular}{cccc}
\hline Number & Percentage & Frequency & Category \\
\hline 1 & $85-100 \%$ & 5 & Very good \\
2 & $75-84 \%$ & 15 & Good \\
3 & $60-74 \%$ & 9 & Enough \\
4 & $50-59 \%$ & 3 & Less \\
5 & $0-49 \%$ & 0 & Very less \\
\hline
\end{tabular}

In the aspect of Japanese vocabulary selection, it is known that the average score of students' writing ability is in a sufficient category, which is $72 \%$.

Table 3. The ability to write students on vocabulary selection aspects

\begin{tabular}{cccc} 
Number & Percentage & Frequency & Category \\
\hline 1 & $85-100 \%$ & 2 & Very good \\
2 & $75-84 \%$ & 6 & Good \\
3 & $60-74 \%$ & 20 & Enough \\
4 & $50-59 \%$ & 4 & Less \\
5 & $0-49 \%$ & 0 & Very less \\
\hline
\end{tabular}

In the aspect of sentence patterns, it is known that $81 \%$ of students have the ability to write in either category.

Table 4. The ability to write students on aspects of sentence patterns

\begin{tabular}{cccc}
\hline Number & Percentage & Frequency & Category \\
\hline 1 & $85-100 \%$ & 5 & Very good \\
2 & $75-84 \%$ & 17 & Good
\end{tabular}




\begin{tabular}{cccc}
3 & $60-74 \%$ & 6 & Enough \\
4 & $50-59 \%$ & 4 & Less \\
5 & $0-49 \%$ & 0 & Very less \\
\hline
\end{tabular}

In the flow aspect, it is known that $82 \%$ of students have the ability to write in either category.

Table 5. Students' writing ability in the flow aspect

\begin{tabular}{cccc}
\hline Number & Percentage & Frequency & Category \\
\hline 1 & $85-100 \%$ & 6 & Very good \\
2 & $75-84 \%$ & 19 & Good \\
3 & $60-74 \%$ & 5 & Enough \\
4 & $50-59 \%$ & 2 & Less \\
5 & $0-49 \%$ & 0 & Very less \\
\hline
\end{tabular}

The ability of students to write on aspects of vocabulary selection is lower than aspects of themes, aspects of sentence patterns, and flow. The theme chosen to have local cultural conservation is "tourist attractions", "traditional celebrations", "traditional cuisine", "traditional souvenirs". Especially on the theme of "traditional celebrations" is a difficulty for students in choosing vocabulary in Japanese. Besides, some Japanese expressions used to occur in mother tongue interference. For example, in "this dish contains vitamins" is "kono ryouri wa bitamin o ninshin shiteiru" in japanesse. For words containing in Japanese have several vocabularies. The word "ninshin shiteiru" is "pregnant"; the right one is "fukumareteiru".

While in the aspect of flow, students' writing ability is included in both categories because the theme chosen is interesting and is related to daily life, such as the theme of "traditional cuisine". With the topics given relating to local culture, students obtain information about local culture through newspapers, magazines, or interviews. The ability to write students through project-based learning has increased, known in table 6. Comparison of the experimental class and the control class below.

Table 6. Comparison of the experimental class and the control class below

\begin{tabular}{|ccccc}
\hline Number & Respondent & Kelas Kontrol & Respondent & $\begin{array}{c}\text { Kelas } \\
\text { Eksperimen }\end{array}$ \\
$\mathbf{1}$ & R1 & 76 & R1 & 78 \\
$\mathbf{2}$ & R2 & 74 & R2 & 76 \\
$\mathbf{3}$ & R3 & 74 & R3 & 78 \\
$\mathbf{4}$ & R4 & 74 & R4 & 82 \\
$\mathbf{5}$ & R5 & 76 & R5 & 78 \\
$\mathbf{6}$ & R6 & 78 & R6 & 84 \\
$\mathbf{7}$ & R7 & 78 & R7 & 86 \\
$\mathbf{8}$ & R8 & 72 & R8 & 82 \\
$\mathbf{9}$ & R9 & 72 & R9 & 82 \\
$\mathbf{1 0}$ & R10 & 72 & R10 & 76 \\
$\mathbf{1 1}$ & R11 & 70 & R11 & 82 \\
$\mathbf{1 2}$ & R12 & 76 & R12 & 82 \\
\hline
\end{tabular}




\begin{tabular}{lllll}
$\mathbf{1 3}$ & $\mathrm{R} 13$ & 70 & $\mathrm{R} 13$ & 84 \\
$\mathbf{1 4}$ & $\mathrm{R} 14$ & 72 & $\mathrm{R} 14$ & 86 \\
$\mathbf{1 5}$ & $\mathrm{R} 15$ & 70 & $\mathrm{R} 15$ & 78 \\
$\mathbf{1 6}$ & $\mathrm{R} 16$ & 74 & $\mathrm{R} 17$ & 78 \\
$\mathbf{1 7}$ & $\mathrm{R} 17$ & 70 & $\mathrm{R} 18$ & 84 \\
$\mathbf{1 8}$ & $\mathrm{R} 18$ & 72 & $\mathrm{R} 19$ & 70 \\
$\mathbf{1 9}$ & $\mathrm{R} 19$ & 74 & $\mathrm{R} 20$ & 72 \\
$\mathbf{2 0}$ & $\mathrm{R} 20$ & 74 & $\mathrm{R} 21$ & 80 \\
$\mathbf{2 1}$ & $\mathrm{R} 21$ & 76 & $\mathrm{R} 22$ & 80 \\
$\mathbf{2 2}$ & $\mathrm{R} 22$ & $\mathrm{R} 23$ & 78 \\
$\mathbf{2 3}$ & $\mathrm{R} 23$ & $\mathrm{R} 24$ & 72 \\
$\mathbf{2 4}$ & $\mathrm{R} 24$ & $\mathrm{R} 25$ & 76 \\
$\mathbf{2 5}$ & $\mathrm{R} 25$ & $\mathrm{R} 26$ & 86 \\
$\mathbf{2 6}$ & $\mathrm{R} 26$ & $\mathrm{R} 27$ & 86 \\
$\mathbf{2 7}$ & $\mathrm{R} 27$ & $\mathrm{R} 28$ & 80 \\
$\mathbf{2 8}$ & $\mathrm{R} 28$ & 66 & $\mathrm{R} 29$ & 78 \\
$\mathbf{2 9}$ & $\mathrm{R} 29$ & 70 & $\mathrm{R} 30$ & 78 \\
$\mathbf{3 0}$ & $\mathrm{R} 30$ & 66 & $\mathrm{R} 31$ & 76 \\
$\mathbf{3 1}$ & $\mathrm{R} 31$ & 64 & $\mathrm{R} 32$ & 79.25 \\
$\mathbf{3 2}$ & & & Average \\
\hline
\end{tabular}

From the comparison of the values above, it can be seen that the average value in the experimental class is higher than the value of the control class.

\section{CONCLUSION}

Based on the results and discussion, the students experienced an increase in the ability to write local culture as a form of cultural conservation with an average value of 79.25 experimental classes higher than the average value of the control class. Besides, it was seen aspects of the theme, including $80 \%$ good category. From the aspect of vocabulary selection, the word category is $72 \%$, the sentence pattern aspect is good $81 \%$, and the flow aspect is good category $82 \%$.

From the results of the above research, it is necessary to do further research on the effectiveness of project-based learning in learning to write.

\section{REFERENCE}

[1] N. Maliawan, "Penerapan Model Pembelajaran Project Based Learning untuk Meningkatkan Hasil Belajar Prakarya dan Kewirausahaan pada Siswa Kelas X IPA2 SMA N 1," J. Pendidik. Tek. Elektro, vol. 6, p. 75, 2017.

[2] T. Markham, Project Based Learning. .

[3] H. Puji, Pendidikan Konservasi. Semarang.

[4] U. Munandar, Pengembangan Kreativitas Anak Berbakat. Jakarta: Rineka Cipta, 2012.

[5] Sugiyono, Metode Penelitian Kualitatif, Kuantitatif, dan R\&D. Bandung, 2011. 
